\title{
ANALISIS SENSITIVITAS HARGA OPSI MENGGUNAKAN METODE GREEK BLACK SCHOLES
}

\author{
Devi Nandita. $\mathrm{N}^{1 \S}$, Komang Dharmawan ${ }^{2}$, Desak Putu Eka Nilakusmawati ${ }^{3}$ \\ ${ }^{1}$ Jurusan Matematika, Fakultas MIPA - Universitas Udayana [Email: devi.nanditha@ gmail.com] \\ ${ }^{2}$ Jurusan Matematika, Fakultas MIPA - Universitas Udayana [Email:dharmawan.komang@gmail.com] \\ ${ }^{3}$ Jurusan Matematika, Fakultas MIPA - Universitas Udayana [Email: nilakusmawati@ unud.ac.id] \\ ${ }^{\S}$ Corresponding Author
}

\begin{abstract}
Sensitivity analysis can be used to carry out hedging strategies. The sensitivity value measures how much the price change of the option influenced by some parameters. The aim of this study is to determine the sensitivity analysis of the buying price of European option by using the Greek method on Black Scholes Formula. From this study we get the values of delta, gamma, theta, vega, and rho. The values of deltas, gamma, vega, and rho are positive, which means that the value of the option is more sensitive than the corresponding parameter. The most sensitive value of gamma is obtained when the stock price approaches the strike price and approaches the expiry date. The value of theta obtained is negative and hence the most sensitive theta value is when the value is getting smaller. While, the most sensitive value of vega is obtained when the stock price is close to the strike price and is far from the expiry date. The most sensitive value of rho is obtained when the stock price gets bigger and farther from the expiry date.
\end{abstract}

Keywords: European Option, Sensitivity Analysis, Black Scholes, Greek Method

\section{PENDAHULUAN}

Pelaksanaan suatu investasi tentunya terdapat risiko, risiko yang dihadapi bisa terjadi karena fluktuasi harga saham. Sehingga untuk mengatasi risiko tersebut investor atau perusahaan dapat melakukan strategi lindung nilai (hedging). Menentukan nilai hedge investor mencari nilai sensitivitas dari suatu saham yang dimiliki. Melakukan lindung nilai (hedging) dengan nilai sensitivitas ini, investor dapat mengurangi risiko yang dihadapinya seperti tingkat suku bunga, kurs valas, dan harga komoditas.

Penentuan harga opsi maupun nilai sensitivitas dapat dilakukan dengan beberapa cara salah satunya adalah formula BlackScholes. Formula Black-Scholes pertama kali dipublikasikan oleh Fisher Black dan Myron Scholes pada tahun 1973. Asumsi yang mendasari formula Black-Scholes adalah perdagangan saham berlangsung dalam selang waktu kontinu, tingkat suku bunga bebas risiko diketahui dan konstan, tidak ada dividen, tidak ada biaya transaksi dan pajak, dimungkinkan adanya short selling terhadap asset, dan drift dan volatilitas yang konstan (Deni, et al., 2016). Formula Black-Scholes untuk menentukan nilai sensitivitas opsi dapat menggunakan metode Greek. Metode Greek pada formula BlackScholes merupakan diferensial parsial dari persamaan Black-Scholes biasa. Metode Greek dapat menentukan nilai delta, gamma, thetha, vega, dan rho.

Berdasarkan uraian tersebut, penelitian ini dilakukan untuk mengetahui analisis sensitivitas harga opsi beli tipe Eropa dengan menggunakan metode Greek pada formula Black-Scholes.

Menurut Sunaryo (2009) prinsip dari hedging adalah menutupi kerugian posisi aset awal dengan keuntungan dari posisi instrumen hedging. Sebelum melakukan hedger hanya memegang sejumlah aset awal. Setelah melakukan hedging, hedger memegang sejumlah 
aset awal dan sejumlah tertentu instrumen hedging.

Sebuah opsi terdapat nilai yang merupakan fungsi dari berbagai macam parameter, ditulis $V(S ; t ; \sigma ; K ; T ; r)$, dengan $S$ merupakan harga dari saham, $t$ adalah waktu, $K$ adalah harga penyerahan (strike price), $T$ adalah batas waktu akhir opsi, $\sigma$ adalah nilai volatilitas saham, dan $r$ bunga bebas risiko (Qiu \& Lorenz, 2009). Pemodelan harga saham dengan menggunakan Black-Scholes mengasumsikan bahwa harga saham tersebut berdistribusi lognormal (Yuliandi, et al., 2015). Menurut Black \& Scholes (1973) harga sebuah opsi beli tipe Eropa pada saham yang tidak membayarkan dividen dengan parameter waktunya $\tau=T-t$, menghasilkan persamaan berikut:

$$
C=S_{0} N\left(d_{1}\right)-K e^{-r \tau} N\left(d_{2}\right)
$$

Metode Greek merupakan teknik untuk mengendalikan risiko yang secara umum dikatakan sebagai sensitivitas nilai opsi dan merupakan persamaan differensial dari BlackScholes. Metode Greek ini terdiri atas delta, gamma, theta, vega, dan rho. Masing-masing pembagian diatas memiliki indikator yang berbeda-beda seperti terhadap harga saham, waktu, volatilitas, dan suku bunga (Yu \& Xie, 2013).

\section{a. Delta}

Delta adalah suatu rasio lindung nilai dan merupakan tingkat perubahaan rata-rata nilai opsi terhadap harga suatu asset. Persamaan delta dapat ditulis sebagai berikut:

$$
\Delta=\frac{\partial C}{\partial S}=N\left(d_{1}\right)
$$

\section{b. Gamma}

Gamma dari sebuah opsi adalah laju perubahan delta terhadap perubahan harga saham, yang dapat dituliskan sebagai berikut:

$$
\Gamma=\frac{\partial \Delta}{\partial S}=\frac{\partial^{2} \mathrm{C}}{\partial S^{2}}=\frac{e^{-d_{1}{ }^{2} / 2}}{S_{0} \sigma \sqrt{2 \pi \imath}}
$$

c. Theta

Theta dari sebuah opsi merupakan perubahaan harga opsi yang dipengaruhi terhadap waktu. Persamaan theta $(\Theta)$ dapat ditulis sebagai berikut:

$$
\Theta=-\frac{S_{0} \sigma}{2 \sqrt{\tau}} N^{\prime}\left(d_{1}\right)-r K e^{-r \tau} N\left(d_{2}\right) .
$$

d. Vega

Vega dari sebuah opsi merupakan perubahaan harga opsi yang dipengaruhi terhadap nilai volatilitas harga saham, yaitu sebagai berikut:

$$
\begin{aligned}
& v=\frac{\partial C}{\partial \sigma} \\
& =S_{0} \sqrt{\tau} N^{\prime}\left(d_{1}\right) .
\end{aligned}
$$

e. Rho

Rho pada opsi didefinisikan sebagai perubahaan harga opsi yang dipengaruhi terhadap tingkat suku bunga. Persamaan rho pada opsi secara umum ditunjukkan sebagai berikut:

$$
\begin{aligned}
& \rho=\frac{\partial C}{\partial r} \\
& =K \tau e^{-r \tau} N\left(d_{2}\right) .
\end{aligned}
$$

\section{METODE PENELITIAN}

Jenis penelitian yang dilakukan yaitu studi kasus terhadap nilai kontrak opsi tipe Eropa. Data yang digunakan yaitu data sekunder berupa data harian harga penutupan (close) saham yang diperdagangkan pada Jakarta Stock Exchange (JKSE) periode 2 Januari 2014 sampai 31 Desember 2016. Data diambil pada situs www.finance.yahoo.com. Langkah-langkah yang digunakan untuk menentukan nilai sensitivitas harga opsi meggunakan metode Greek adalah:

1. Mengumpulkan indeks harga saham harian yang diperdagangkan pada Jakarta Stock Exchange (JKSE).

2. Menentukan nilai return (tingkat pengembalian) menggunakan persamaan:

$$
R_{t}=\ln \left(\frac{S_{t+1}}{S_{t}}\right) \text {. }
$$

3. Menentukan nilai volatilitas $(\sigma)$ harga saham menggunakan persamaan:

$$
\sigma=\sqrt{\operatorname{var} \times k} \text {. }
$$


4. Menentukan harga saham awal $\left(S_{0}\right)$ berdasarkan data harian harga saham. dan harga penyerahan $(K)$, tingkat suku bunga bebas risiko $(r=0,065)$, waktu jatuh tempo $(T)$, dan sisa waktu jatuh tempo $(t)$.

5. Setelah mendapatkan semua nilai dari variabel akan dilanjutkan menentukan nilai opsi beli dengan menggunakan formula Black Scholes pada persamaan (1).

6. Selanjutnya mencari nilai sensitivitas berupa delta gamma, theta, vega, dan rho dengan menggunakan persamaan (2), (3), (4), (5), dan (6).

7. Melakukan interpretasi hasil analisis sensitivitas.

\section{HASIL DAN PEMBAHASAN}

Karakteristik data ditentukan menggunakan nilai tingkat pengembalian (return) menggunakan persamaan (7), contoh perhitungan saat $t=1$ sebagai berikut:

$$
R_{1}=\ln \left(\frac{1801,27}{1835,83}\right)=-0,01900294
$$

Nilai statistika deskriptif ini diperoleh dengan menghitung nilai mean, variance, skewenes, dan kurtosis, diperoleh hasil pada Tabel 1.

Tabel 1. Nilai Statistika Deskriptif Data Return

\begin{tabular}{|l|c|}
\hline \multicolumn{1}{|c|}{ Karakteristik } & Nilai \\
\hline Mean & 0,0010315 \\
\hline Variance & 0,0002537 \\
\hline Skewness & $-0,102782$ \\
\hline Kurtosis & 1,7006744 \\
\hline
\end{tabular}

Tabel 1. menunjukkan bahwa model data return saham PT. Telkom memiliki bentuk yang tidak simetris. Hal ini ditunjukkan dengan karakteristik data yang memiliki nilai skewness negatif yang mengakibatkan data menceng (skew) ke kiri, serta diperoleh nilai kurtosis yang tidak normal yaitu 1,70067. Nilai kurtosis yang diperoleh tersebut cukup kecil sedangkan nilai kurtosis yang berdistribusi normal adalah 3. Hal ini berarti bahwa sebaran data dari PT. Telkom tidak normal, dikarenakan pada waktu tertentu data saham dapat melonjak naik maupun turun. Nilai volatilitas tahunan dihitung menggunakan persamaan (8) sehingga menghasilkan nilai sebesar 0,24779.

Penentuan nilai kontrak opsi tipe Eropa terdapat variabel-variabel yang digunakan diantaranya:

1. Harga Saham Awal $\left(S_{0}\right)$

Harga saham awal dari PT. Telekomunikasi Indonesia. Tbk dapat dilihat berdasarkan pada data harian harga penutupan (close) periode 2014 sampai 2016, dengan mengambil harga saham mulai dari yang terkecil yaitu seharga Rp. 2.000 sampai harga saham yang terbesar yaitu seharga Rp. 5.000. Harga saham yang akan digunakan sebagai interpretasi adalah Rp. 4.100.

2. Harga Kesepakatan $(K)$

Pada penelitian ini ditentukan harga kesepakatan antara penjual dan pembeli yaitu sebesar Rp. 3.850.

3. Tingkat Suku Bunga $(r)$

Tingkat suku bunga bebas risiko yang digunakan pada penelitian ini adalah tingkat suku bunga Bank Indonesia yaitu sebesar $6,5 \%$ dapat yang diakses pada situs http://www.bi.go.id/id/Default.aspx.

4. Waktu Jatuh Tempo

Nilai waktu jatuh tempo $(T)$ yang digunakan pada penelitian ini yaitu sebesar 0,5 tahun. Dalam menentukan sisa waktu jatuh tempo $(t)$ penulis membaginya menjadi tiga bagian yang terdiri dari 4 bulan, 2 bulan, dan sampai pada waktu jatuh tempo itu sendiri yaitu 6 bulan. Apabila dijadikan tahun maka 0,33; 0,17 ; dan 0. Dengan demikian diperoleh nilai $\tau(T-t)$ sebesar 0,$17 ; 0,33$; dan 0,5 .

Selanjutnya setelah menentukan nilai variabel yang diperlukan, harga opsi beli tipe Eropa dihitung dengan persamaan BlackScholes pada $\tau=0,17$ sebagai berikut.

$$
\begin{aligned}
C= & S_{0} N\left(d_{1}\right)-K e^{-r \tau} N\left(d_{2}\right) \\
C= & 4100 \times(0,780838732)- \\
& 3850 \times e^{-0,065 \times 0,17} \times(0,7494822) \\
C= & 347,6415923
\end{aligned}
$$

Sehingga harga opsi beli tipe Eropa secara terinci dapat dilihat pada Tabel 2 dan disajikan dalam bentuk grafik pada Gambar 1 . 
Tabel 2. Nilai Opsi Beli Tipe Eropa

\begin{tabular}{|c|c|r|r|r|}
\hline No & $\begin{array}{c}\text { Harga } \\
\text { Saham } \\
(\mathrm{Rp})\end{array}$ & $\begin{array}{c}\text { Opsi Beli 2 Bulan } \\
\text { Sebelum Jatuh Tempo }\end{array}$ & $\begin{array}{c}\text { Opsi Beli 4 Bulan } \\
\text { Sebelum Jatuh Tempo }\end{array}$ & $\begin{array}{c}\text { Opsi Beli 6 Bulan } \\
\text { Sebelum Jatuh Tempo }\end{array}$ \\
\hline 1 & 2.000 & $6,26322 \times 10^{-9}$ & 0,00034 & 0,02261 \\
\hline 2 & 2.900 & 0,40245 & 6,05900 & 19,634955 \\
\hline 3 & 3.800 & 151,15813 & 230,93549 & 300,89889 \\
\hline 4 & 4.100 & 347,64159 & 427,07854 & 499,15828 \\
\hline 5 & 4.700 & 895,41910 & 947,24729 & 1004,74676 \\
\hline
\end{tabular}

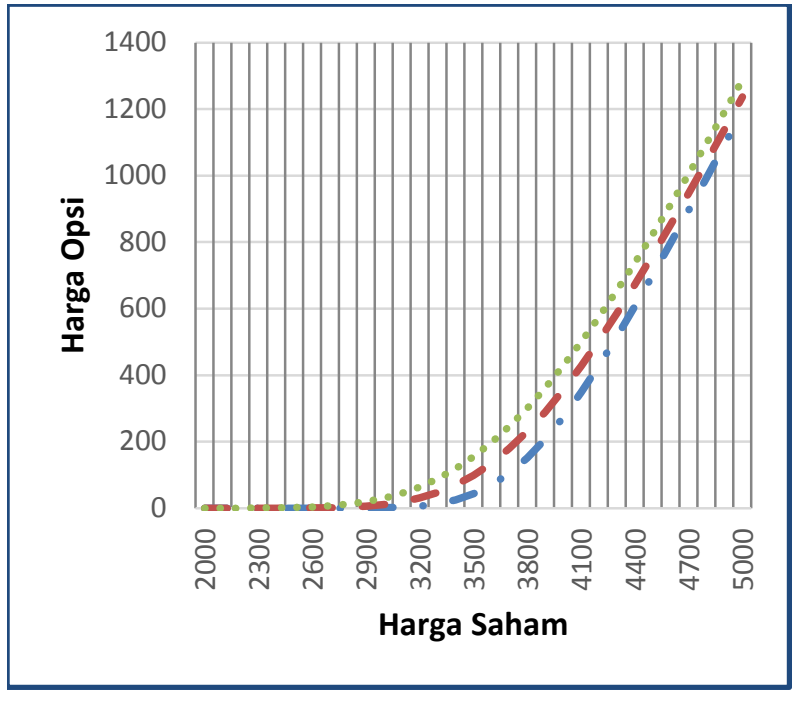

Gambar 1. Grafik Harga Opsi Beli Tipe Eropa

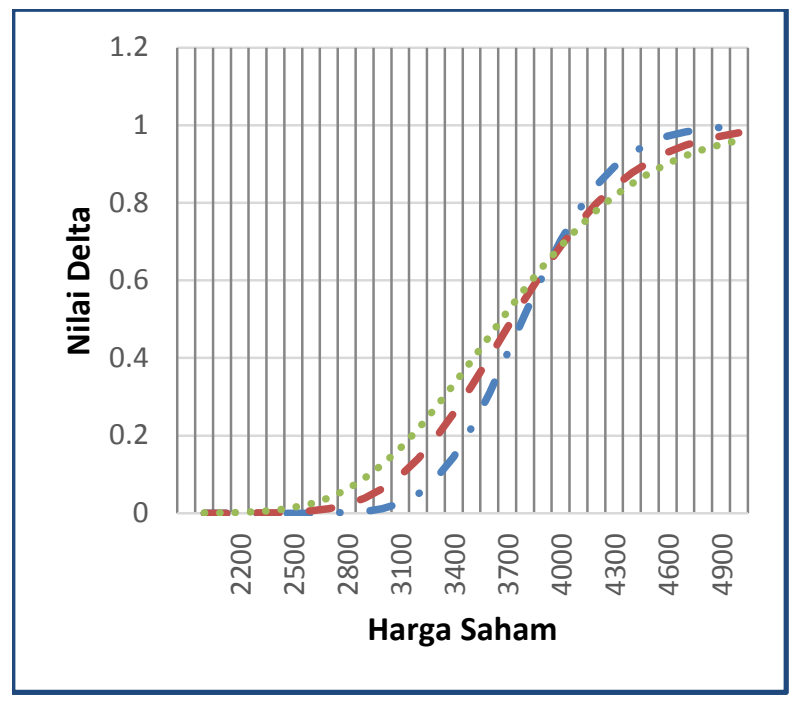

Gambar 2. Grafik Nilai Delta - Grafik 2 Bulan Sebelum Jatuh Tempo
- - Grafik 4 Bulan Sebelum Jatuh Tempo
... Grafik 6 Bulan Sebelum Jatuh Tempo

\section{Nilai Sensitivitas Harga Opsi}

\section{a. Penentuan Nilai Delta}

Delta pada harga saham Rp. 4.100 dihitung dengan persamaan yang merupakan fungsi distribusi kumulatif normal baku dari $d_{1}$.

$d_{1}=\frac{\ln \left(\frac{S_{0}}{K}\right)+\left(r+\frac{\sigma^{2}}{2}\right) \tau}{\sigma \sqrt{\tau}}$

$$
\begin{aligned}
& d_{1}=\frac{\ln \left(\frac{4100}{3850}\right)+\left(0,065+\frac{0,24779313^{2}}{2}\right) 0,17}{0,24779313 \times \sqrt{0,17}} \\
& d_{1}=0,77502898 \\
& =0,780838732
\end{aligned}
$$

Nilai delta yang diperoleh secara terinci dapat dilihat Tabel 3 dan disajikan dalam bentuk grafik pada Gambar 2 .

Tabel 3. Nilai Delta pada Opsi

\begin{tabular}{|c|c|r|r|r|}
\hline No & $\begin{array}{c}\text { Harga Saham } \\
(\mathrm{Rp})\end{array}$ & $\begin{array}{c}\text { Nilai Delta 2 Bulan } \\
\text { Sebelum Jatuh Tempo } \\
(\tau=0,17)\end{array}$ & $\begin{array}{c}\text { Nilai Delta 4 Bulan } \\
\text { Sebelum Jatuh Tempo } \\
(\tau=0,33)\end{array}$ & $\begin{array}{c}\text { Nilai Delta 4 Bulan } \\
\text { Sebelum Jatuh Tempo } \\
(\tau=0,5)\end{array}$ \\
\hline 1 & 2.000 & $2,038 \times 10^{-10}$ & $5,959 \times 10^{-6}$ & 0,00026 \\
\hline 2 & 2.900 & 0,00447 & 0,03846 & 0,08945 \\
\hline 3 & 3.800 & 0,51248 & 0,55173 & 0,57867 \\
\hline 4 & 4.100 & 0,78084 & 0,74660 & 0,73636 \\
\hline 5 & 4.700 & 0,98265 & 0,94774 & 0,92097 \\
\hline
\end{tabular}




\section{b. Penentuan Nilai Gamma}

Untuk menghitung nilai gamma dapat menggunakan persamaan (3) dengan harga saham Rp. 4.100 sebagai berikut.

$$
\begin{aligned}
& \Gamma \quad=\frac{e^{-d_{1}{ }^{2} / 2}}{S_{0} \sigma \sqrt{2 \pi \tau}} \\
& \Gamma \quad=\frac{e^{-0,7808387^{2} / 2}}{4100 \times 0,24779313 \times \sqrt{2(3,14) \times 0,17}} \\
& \Gamma \quad=\frac{e^{-0,7808387^{2} / 2}}{1015,95 \times 1,03351} \\
& \Gamma: 4,62579 \times 10^{-5}
\end{aligned}
$$

Maka nilai gamma dengan masingmasing $\tau$ secara terinci diperoleh pada
Tabel 4 dan disajikan dalam bentuk grafik dapat dilihat pada Gambar 3.

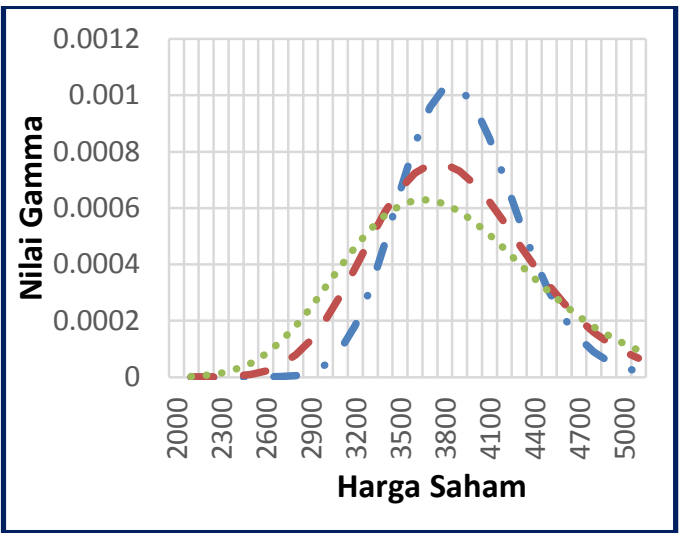

Gambar 3. Grafik Nilai Gamma

Tabel 4. Nilai Gamma pada Opsi

\begin{tabular}{|c|c|c|c|c|}
\hline No & $\begin{array}{c}\text { Harga } \\
\text { Saham } \\
(\mathrm{Rp})\end{array}$ & $\begin{array}{c}\text { Nilaii Gamma 2 Bulan } \\
\text { Sebelum Jatuh Tempo } \\
(\tau=0,17)\end{array}$ & $\begin{array}{c}\text { Nilai Gamma 4 Bulan } \\
\text { Sebelum Jatuh Tempo } \\
(\tau=0,33)\end{array}$ & $\begin{array}{c}\text { Nilaii Gamma 6 Bulan } \\
\text { Sebelum Jatuh Tempo } \\
(\tau=0,5)\end{array}$ \\
\hline 1 & 2.000 & $4,18962 \times 10^{-13}$ & $1,22273 \times 10^{-8}$ & $5,43166 \times 10^{-7}$ \\
\hline 2 & 2.900 & $2,89695 \times 10^{-6}$ & $2,57433 \times 10^{-5}$ & $6,13697 \times 10^{-5}$ \\
\hline 3 & 3.800 & $6,73608 \times 10^{-5}$ & $9,31067 \times 10^{-5}$ & 0,000113325 \\
\hline 4 & 4.100 & $4,62579 \times 10^{-5}$ & $6,98167 \times 10^{-5}$ & $8,7721 \times 10^{-5}$ \\
\hline 5 & 4.700 & $5,85987 \times 10^{-6}$ & $2,03298 \times 10^{-5}$ & $3,4503 \times 10^{-5}$ \\
\hline
\end{tabular}

\section{c. Penentuan Nilai Theta}

Untuk menghitung nilai theta dapat menggunakan persamaan (4), dengan saham awal Rp. 4.100 pada $\tau=$ 0,17 diperoleh nilai berikut.
$\Theta \frac{\sigma}{\sqrt{\tau}} N^{\prime}\left(d_{1}\right)-r K e^{-r \tau} N\left(d_{2}\right)$
$\Theta-\left(\frac{4100(0,24779313)}{2 \sqrt{0,17}} \times 0,29544473\right)$
$-0,065 \times 3850 \times e^{-0,065 \times 0,17}(0,7494822)$
$\Theta=-549,4913947$

Maka nilai theta dengan masing-masing $\tau$ secara terinci diperoleh pada Tabel 5 dan dapat disajikan dalam bentuk grafik pada Gambar 4. Selanjutnya diperoleh nilai theta berdasarkan perubahan nilai $\tau$ yaitu dari 0,01 sampai 0,5 dengan harga saham awal Rp. 2.000, Rp. 3.000, Rp. 4.000, Rp. 5.000 pada Tabel 6 serta grafik nilai theta dengan perubahan waktu dapat dilihat pada Gambar 5.

Tabel 5. Nilai Theta pada Opsi

\begin{tabular}{|c|c|c|c|r|}
\hline No & $\begin{array}{c}\text { Harga } \\
\text { Saham } \\
(\mathrm{Rp})\end{array}$ & $\begin{array}{c}\text { Nilai Theta 2 Bulan } \\
\text { Sebelum Jatuh Tempo } \\
(\tau=0,17)\end{array}$ & $\begin{array}{c}\text { Nilai Theta 4 Bulan } \\
\text { Sebelum Jatuh Tempo } \\
(\tau=0,33)\end{array}$ & $\begin{array}{c}\text { Nilai Theta 6 Bulan } \\
\text { Sebelum Jatuh Tempo } \\
(\tau=0,5)\end{array}$ \\
\hline 1 & 2.000 & $-8,1056 \times 10^{-7}$ & $-0,01255$ & $-0,37882$ \\
\hline 2 & 2.900 & $-12,22118$ & $-59,06469$ & $-97,72875$ \\
\hline 3 & 3.800 & $-572,07677$ & $-445,47468$ & $-383,81576$ \\
\hline 4 & 4.100 & $-549,49139$ & $-454,22064$ & $-398,48226$ \\
\hline 5 & 4.700 & $-302,59026$ & $-336,25699$ & $-337,35190$ \\
\hline
\end{tabular}




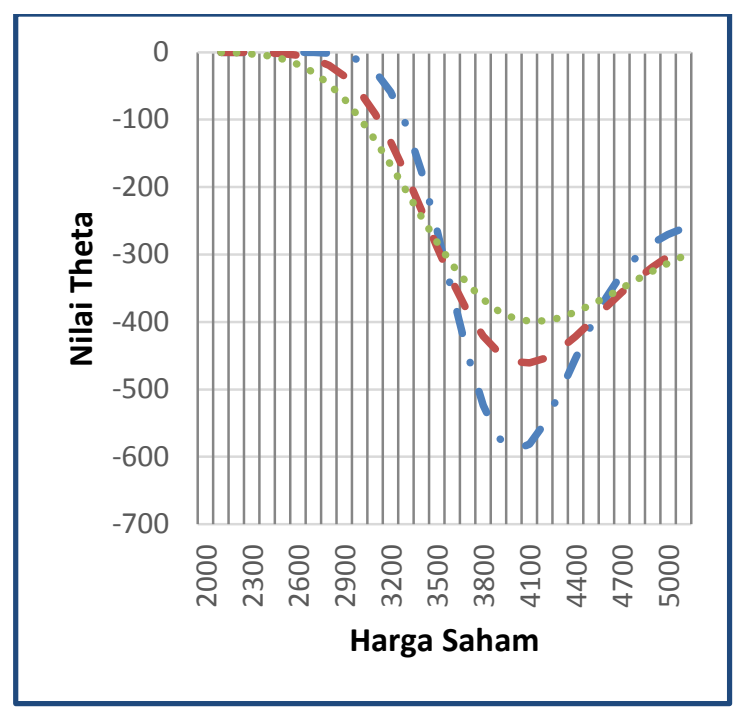

Gambar 4. Grafik Nilai Theta

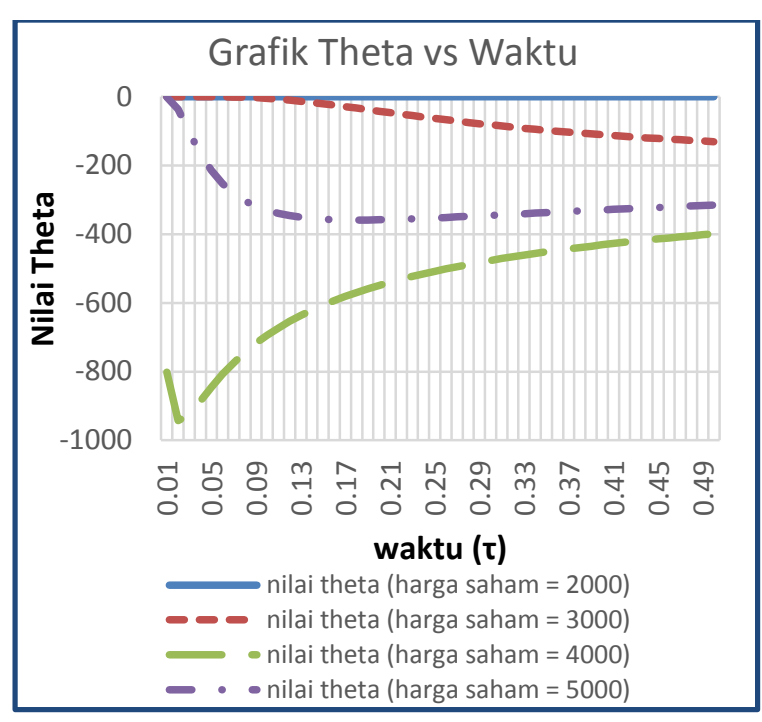

Gambar 5. Grafik Nilai Theta vs Waktu

Tabel 6. Nilai Theta dengan Perubahan Waktu ( $\tau)$

\begin{tabular}{|c|c|r|r|r|r|}
\hline No & Waktu $(\tau)$ & $\begin{array}{c}\text { Nilai Theta } \text { (harga } \\
\text { saham = Rp. 2.000) }\end{array}$ & $\begin{array}{c}\text { Nilai Theta } \text { (harga } \\
\text { saham = Rp. } \\
3.000)\end{array}$ & $\begin{array}{c}\text { Nilai Theta } \\
\text { (harga saham }= \\
\text { Rp. 4.000) }\end{array}$ & $\begin{array}{c}\text { Nilai Theta } \text { (harga } \\
\text { saham = Rp. 5.000) }\end{array}$ \\
\hline 1 & 0,01 & $-5,594 \times 10^{-149}$ & $-2,157 \times 10^{-19}$ & $-801,62478$ & $-1,24513$ \\
\hline 2 & 0,17 & $-8,1056 \times 10^{-7}$ & $-28,70040$ & $-580,98579$ & $-358,22679$ \\
\hline 3 & 0,3 & $-0,00455$ & $-81,69799$ & $-476,61095$ & $-345,18205$ \\
\hline 4 & 0,33 & $-0,01255$ & $-91,55363$ & $-460,98344$ & $-340,42043$ \\
\hline 5 & 0,5 & $-0,37881$ & $-130,56496$ & $-398,98850$ & $-315,24321$ \\
\hline
\end{tabular}

\section{d. Penentuan Nilai Vega}

Untuk menghitung nilai vega dapat menggunakan persamaan (5), dengan saham awal Rp. 4.100 pada $\tau=$ 0,17 diperoleh nilai berikut.

$v S_{0} \sqrt{\tau} N^{\prime}\left(d_{1}\right)$

$v=4100 \times \sqrt{0,17}(0,29544473)$

$v=499,4414329$
Maka nilai vega dengan masing-masing $\tau$ secara terinci diperoleh pada Tabel 7 dengan grafik pada Gambar 6 . Selanjutnya nilai vega diperoleh berdasarkan perubahan nilai $\tau$ yaitu dari 0,01 sampai 0,5 dengan harga saham awal Rp. 2.000, Rp. 3.000, Rp. 4.000, Rp. 5.000 pada Tabel 8 dan grafiknya dapat dilihat pada Gambar 7.

Tabel 7. Nilai Vega pada Opsi

\begin{tabular}{|c|c|r|r|r|}
\hline No & $\begin{array}{c}\text { Harga } \\
\text { Saham } \\
(\mathrm{Rp})\end{array}$ & $\begin{array}{c}\text { Nilai Vega 2 Bulan } \\
\text { Sebelum Jatuh Tempo } \\
(\tau=0,17)\end{array}$ & $\begin{array}{c}\text { Nilai Vega 4 Bulan } \\
\text { Sebelum Jatuh Tempo } \\
(\tau=0,33)\end{array}$ & $\begin{array}{c}\text { Nilai Vega 6 Bulan } \\
\text { Sebelum Jatuh Tempo } \\
(\tau=0,5)\end{array}$ \\
\hline 1 & 2.000 & $1,0764 \times 10^{-6}$ & 0,03141 & 1,39548 \\
\hline 2 & 2.900 & 15,64833 & 139,05669 & 331,49779 \\
\hline 3 & 3.800 & 624,74889 & 863,53353 & 1051,05061 \\
\hline 4 & 4.100 & 499,44143 & 753,80309 & 947,11334 \\
\hline 5 & 4.700 & 83,14093 & 288,44330 & 489,53791 \\
\hline
\end{tabular}




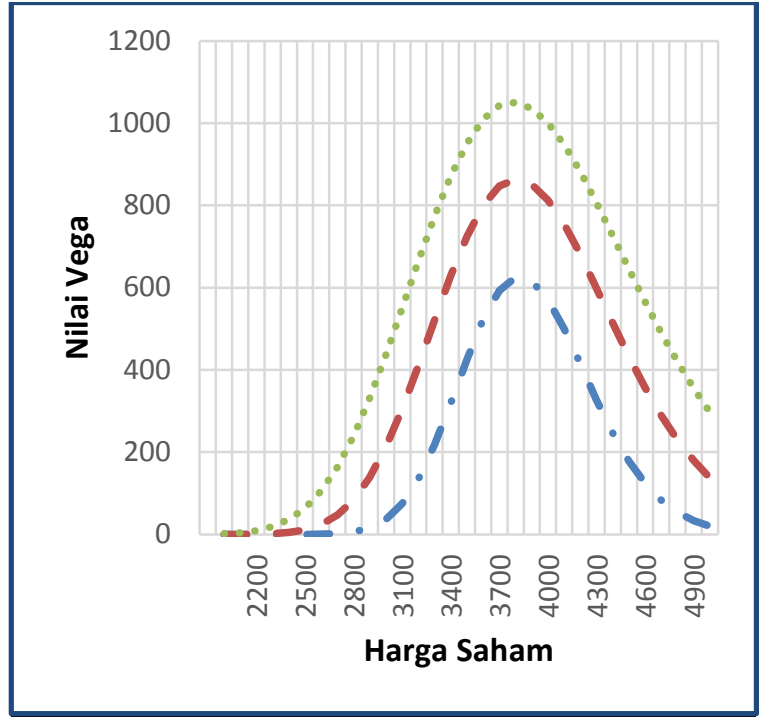

Gambar 6. Grafik Nilai Vega

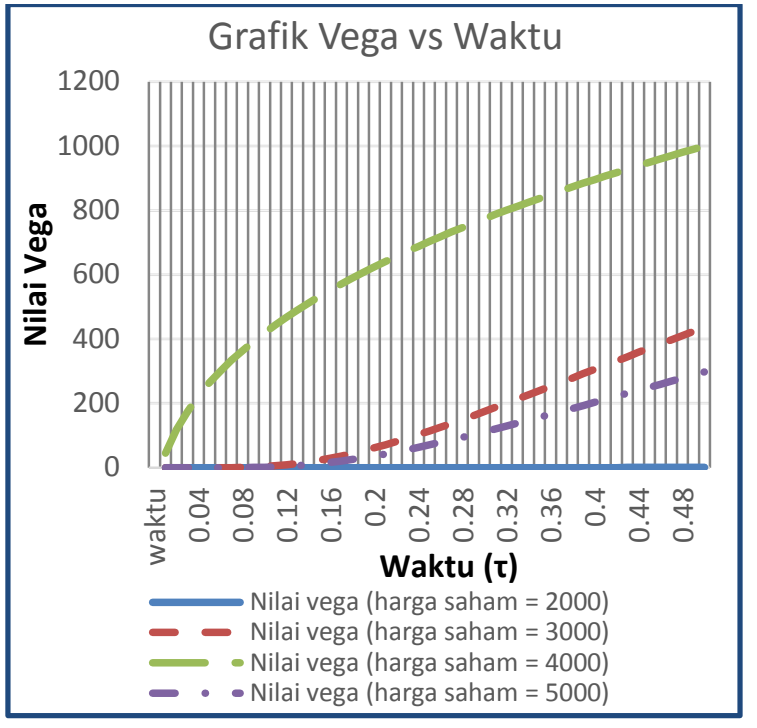

Gambar 7. Grafik Nilai Vega vs Waktu

Tabel 8. Nilai Vega dengan Perubahan Waktu (ז)

\begin{tabular}{|r|r|r|r|r|r|}
\hline No & $\begin{array}{c}\text { Waktu } \\
(\tau)\end{array}$ & $\begin{array}{c}\text { Nilai Vega }(\text { harga } \\
\text { saham = Rp. 2.000) }\end{array}$ & $\begin{array}{c}\text { Nilai Vega } \\
\text { (harga saham }= \\
\text { Rp. 3.000) }\end{array}$ & $\begin{array}{c}\text { Nilai Vega } \text { (harga } \\
\text { saham = Rp. 4.000) }\end{array}$ & $\begin{array}{c}\text { Nilai Vega } \text { (harga } \\
\text { saham = Rp. 5.000) }\end{array}$ \\
\hline 1 & 0,08 & $6,8048 \times 10^{-17}$ & 0,88073 & 364,31130 & 0,356538 \\
\hline 2 & 0,17 & $1,0764 \times 10^{-6}$ & 36,47706 & 570,72407 & 20,49246 \\
\hline 3 & 0,33 & 0,03141 & 213,08321 & 812,85125 & 137,86578 \\
\hline 4 & 0,41 & 0,27453 & 318,58229 & 907,00488 & 212,24834 \\
\hline 5 & 0,5 & 1,39548 & 436,53607 & 1000,12846 & 297,22408 \\
\hline
\end{tabular}

\section{e. Penentuan Nilai Rho}

Untuk menghitung nilai rho dapat menggunakan persamaan (6), dengan saham awal Rp. 4.100 pada $\tau=$ 0,17 diperoleh nilai berikut.

$$
\begin{aligned}
& \rho K \tau e^{-r \tau} N\left(d_{2}\right) \\
& \rho 1,17 \times e^{-0,065 \times 0,17} \times 0,7494822 \\
& \rho=485,1455
\end{aligned}
$$

Maka nilai rho dengan masing-masing $\tau$ secara terinci diperoleh pada Tabel 9 dan dalam bentuk grafik dapat dilihat pada Gambar 8. Selanjutnya nilai rho diperoleh berdasarkan perubahan nilai $\tau$ yaitu dari 0,01 sampai 0,5 dengan harga saham awal Rp. 2.000, Rp. 3.000, Rp. 4.000, Rp. 5.000 pada Tabel 10 dan grafiknya dapat dilihat pada Gambar 9.

Tabel 9. Nilai Rho pada Opsi

\begin{tabular}{|c|c|r|r|r|}
\hline No & $\begin{array}{c}\text { Harga } \\
\text { Saham } \\
(\mathrm{Rp})\end{array}$ & $\begin{array}{c}\text { Nilai Rho 2 Bulan } \\
\text { Sebelum Jatuh Tempo } \\
(\tau=0,17)\end{array}$ & $\begin{array}{c}\text { Nilai Rho 4 Bulan } \\
\text { Sebelum Jatuh } \\
\text { Tempo } \\
(\tau=0,33)\end{array}$ & $\begin{array}{c}\text { Nilai Rho 6 Bulan } \\
\text { Sebelum Jatuh } \\
\text { Tempo } \\
(\tau=0,5)\end{array}$ \\
\hline 1 & 2.000 & $6.824 \times 10^{-8}$ & 0,00382 & 0,25408 \\
\hline 2 & 2.900 & 2,13579 & 34,81078 & 119,89137 \\
\hline 3 & 3.800 & 305,66291 & 615,65855 & 949,02029 \\
\hline 4 & 4.100 & 485,14553 & 869,21845 & 1259,95459 \\
\hline 5 & 4.700 & 632,91489 & 1157,34883 & 1661,90593 \\
\hline
\end{tabular}




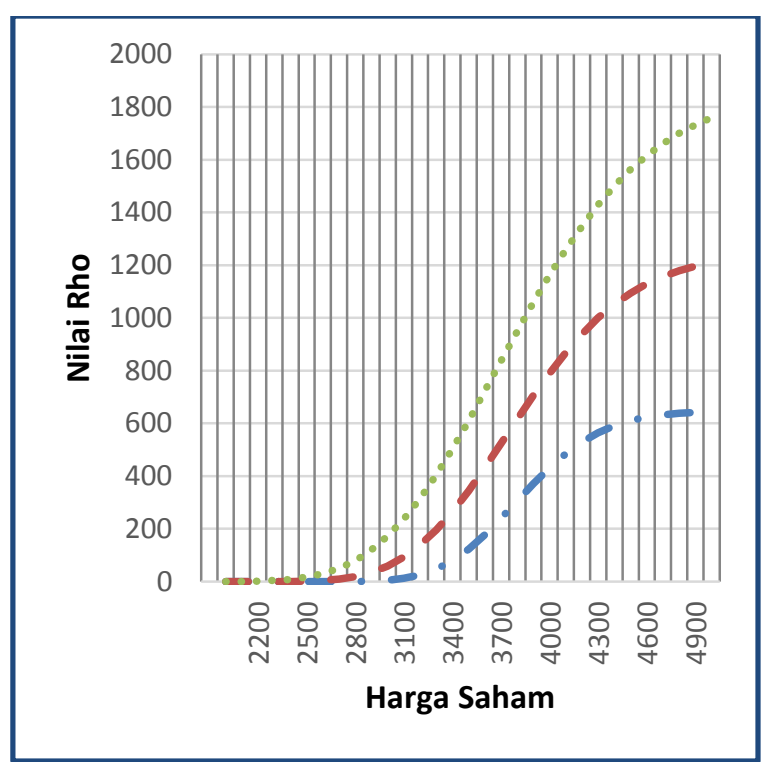

Gambar 8. Grafik Nilai Rho

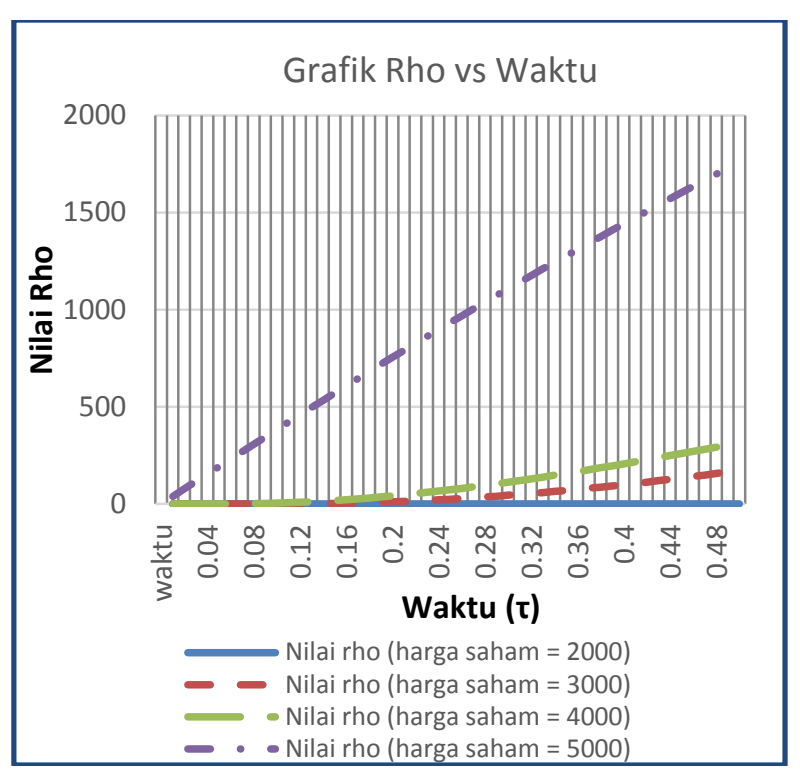

Gambar 9. Grafik Nilai Rho vs Waktu

Tabel 10. Nilai Rho dengan Perubahan Waktu ( $\boldsymbol{\tau}$ )

\begin{tabular}{|c|r|r|r|r|r|}
\hline No & $\begin{array}{c}\text { Waktu } \\
(\tau)\end{array}$ & $\begin{array}{c}\text { Nilai Rho } \\
\text { (harga saham }=\text { Rp. } \\
2.000)\end{array}$ & $\begin{array}{c}\text { Nilai } \text { Rho } \text { (harga } \\
\text { saham = Rp. 3,000) }\end{array}$ & $\begin{array}{c}\text { Nilai Rho (harga } \\
\text { saham = Rp. 4.000) }\end{array}$ & $\begin{array}{c}\text { Nilai } \text { Rho (harga } \\
\text { saham = Rp. 5.000) }\end{array}$ \\
\hline 1 & 0.08 & $2,0453 \times 10^{-18}$ & 0,06607 & 1,43096 & 306,37738 \\
\hline 2 & 0.17 & $6,8239 \times 10^{-8}$ & 5,53361 & 25,76815 & 644,42194 \\
\hline 3 & 0.33 & 0,00382 & 58,65262 & 138,41936 & 1209,08475 \\
\hline 4 & 0.41 & 0,04124 & 105,98343 & 216,36487 & 1473,52589 \\
\hline 5 & 0.5 & 0,25408 & 172,26399 & 315,20681 & 1759,14916 \\
\hline
\end{tabular}

\section{SIMPULAN DAN SARAN}

\section{Simpulan}

Berdasarkan hasil dan pembahasan menunjukan bahwa nilai delta yang memiliki sensitivitas tertinggi pada saat harga saham melebihi harga kesepakatan dan mendekati waktu jatuh tempo. Nilai gamma paling sensitif diperoleh pada saat harga saham mendekati harga kesepakatan dan mendekati waktu jatuh tempo. Nilai theta yang diperoleh bernilai negatif sehingga nilai theta yang paling sensitif adalah nilai theta terkecil. Nilai vega paling sensitif diperoleh pada saat harga saham mendekati harga kesepakatan dan jauh dari waktu jatuh tempo. Nilai rho paling sensitif diperoleh pada saat harga saham semakin besar dan jauh dari waktu jatuh tempo.

\section{Saran}

Adapun hal yang dapat disarankan dalam penelitian selanjutnya yaitu menggunakan tipe opsi yang berbeda seperti tipe Amerika dan tipe Barrier serta memasukan faktor lain yang memengaruhi harga opsi seperti pembagian dividen, pembayaran komisi dan pajak.

\section{DAFTAR PUSTAKA}

Black, F. \& Scholes, M., 1973. The Pricing of Options and Corporate Liabilities. The Journal of Political Economy, 81(3), pp. 637-654.

Deni, P. A., Dharmawan, K. \& Ghandiadi, G., 2016. Penentuan Harga Opsi dan Nilai Hedge Menggunakan Persamaan NonLinear Black Scholes. E-Jurnal Matematika, 5(1), pp.27-31. 
Qiu, Y. \& Lorenz, J., 2009. A Non-Linear Black-Scholes Equation. International. Jurnal. Business Performance and Supply Chain Modelling, 1(1), pp. 33-40.

Sunaryo, T., 2009. Manajemen Risiko Finansial. Jakarta: Salemba Empat.

Yuliandi, T. D., Devianto, D. \& Yozza, H., 2015. Perbandingan Metode Black scholes dan Simulasi Monte Carlo dalam Penentuan Harga Opsi Eropa. Jurnal Matematika UNAND, 5(1), pp. 7-16.

Yu, X. \& Xie, X., 2013. One Derivations of Black Scholes Greek Letters. Research Journal of Finance and Accounting, 4(6), pp. 2222-2847. 